\title{
Parenting in Day Care to Develop Autonomy and Social-Emotional Ability in Children Ages 2-3 Year
}

\author{
Rachma Hasibuan, Noer Alfiah Marlita \\ Universitas Negeri Surabaya, Surabaya, Indonesia \\ e-mail: rachmahasibuan@unesa.ac.id
}

\begin{abstract}
Focus of the research: 1) How parenting day care can develop independence in children aged 2-3 Years ?; 2) How does the parenting day care can develop socio-emotional abilities in children aged 2-3 Years ?; 3) How does the parenting day care to develop independence and social-emotional abilities of children aged 2-3 years. The approach in this study uses descriptive qualitative data collection techniques performed triangulation (combined), data analysis is inductive/ qualitative. Determination of research on the subject of qualitative research is purposive day care with age range of 2-3 years old children and has been at day care at least 2 months, the subject of study is five children. Conclusions research on parenting in developing emotional independence and social skills in children aged 2-3 years, providing parenting assistance continuously through habituations to begin providing assistance and giving examples of activities that will be performed by children, because it has a role in planting value independence and social-emotional. This is evident in children aged 2-3 years in day care were able to show an increase in the ability of self-reliance and social-emotional with approximately between 2-3 months after the child in day care.
\end{abstract}

Keywords: Parenting, Self Reliance, Social-Emotional, Day Care

\section{INTRODUCTION}

Human development happens rapidly, especially on their childhood stage. The first three years is the most sensitive times since it is associated to the golden age or rapid brain development period. The rapidity of brain development in this period can be noticed by brain mass development, from $400 \mathrm{gr}$ when babies are newborns, to three times of it at the end of the third year. Children learn more in their first three years, than the rest of their life. (Ford, 2000:161). Emotional factors (affection, safety) and stimulations must be made into consideration, since golden age is a perfect period to enrich children while also maximizing the discovery of children intelligence potentials.

Taylor (in Putra and Dwilestari, 2012:5) stated that we all have the same brain cells but their connections constantly change along with our experience. This means although newborn babies may have the same potential, they will be different one to another because they have different experiences and treatments. These experience and treatment may include parenting, nutritional intake, active stimulus, and environment arrangement (Putra and Dwilestari, 2012:5).

The earlier stimulation will yield in better children development. The more optimal children development can be achieved by giving knowledge enriching stimulations. It is also mentioned that brain tissue on well stimulated children will develop up to $80 \%$ at 3 years of age. On the contrary, children without exposure to stimulations will have less developed brain tissue resulting in declining brain function. This prevent children from going well developed. In fact, Ibuka (in Putra and Dwilestari, 2012:5) emphasized that the first 3 years of children life is a critical period. This golden period must be well used by giving children proper education. Education does not always mean school. 
Quality parenting may also be done by parents and surrounding people.

Parents, as the main aspect in the life of children, are expected to give special consideration on children growth and development since early on, because they affect the future life of children. This is also emphasized in Law No. 4 of 1979 Republik Indonesia on children well-being which instructed that parents are the first and primary education responsible in children well-being physically, mentally, spiritually, and also socially. Children must receive excellent care, parenting and also receive optimal physical, mental, spiritual, and social development since early on, because they are asset to family, society, and also to the nation.

However for various reasons, some children do not receive optimal parenting from their parents, due to the parents do not have enough time caused by busy working. Parents working together to manage with living cost is a common norm today. Nanny services or taking children to relatives when working often taken as solution to taking care of the children. Along with many unpleasant accidents involving nannies or unavailibility of relatives to take care of the children, arise the concern of parents on parenting children growth and development.

Such condition inspired the born of day care business. Day care comes as a social well-being parenting facility, temporarily replacing family for children with working or lack of time parents, unable to fulfill parenting need of their children. Day care institutions provide appropriate solution in helping to optimize all aspects of children development. Children can grow and develop according to their age under supervision of experienced nannies. A good day care environment, in term of indoor and outdoor lay-out, toys and same age playmates along with good administration will be influential in all aspects of children development.

According to Patmodewo (National Education Department, 2007), several reasons for parents trusting their children to day care are : (1) the need to routinely delegate child care responsibility for a while for work, (2) desire to give children the chance to interact with children of the same age, (3) to keep children well stimulated and substitute caring while mother is working.

Putting children in day care is expected to cause children to be consistently adaptive in accordance with children's developing competence resulting in appropriate and independent children, since independence and social-emotional competency are crucial for children to achieve a quality life in the future as emphasized by Goleman (in Putra and Dwilestari, 2012:13) that human life is determined more by social emotional intelligence than rational intelligence.

A more optimal children development will be a strong drive to explore both the environment and themselves. Children will always eager to try new things they observe, sense and then replicate. Aspects related to children's autonomy and social emotional can be developed using various proper methods incorporated in day care parenting.

\section{LITERATURE REVIEW}

\subsection{Early Childhood Education}

Early Childhood Education (ECE) was decisively instructed by Law No. 20 of 2003 on National Education System. The Law declared that early childhood education is an education stage before elementary education stage given to children of newly born age up to 6 years old, done by using educational stimulations to assist physical and mental development of children for them to be ready for the next stage of education. PAUD can be implemented in many ways, be it informally, nonformally, and also formally.

Informal way can be done by the family. Nonformal way can be : (a) Children Care Center (day care), (b) Playgroup, and other equal forms such as Satuan Pendidikan Sejenis (SPS), Pos PAUD Terpadu (PPT), while the formal way take the form of (a) Kindergarten (TK), (b) Islamic Kindergarten (RA).

Early childhood education is an educational institution that gratifies in building the basics of growth and physical development (fine and gross motor coordination), intelligence (reasoning, innovation, emotional intelligence, spiritual intelligence), social emotional (attitude, behavior, and religion), language and communication in accordance with early children uniqueness and development stages.

Majority of people assume that proper competences are not necessarily needed by adults practicing early childhood education. They also think PAUD does not need to be professional. This opinion is incorrect. Whenever a PAUD is held at home by the mothers, those mothers are required to learn, extending their knowledge on children learning process, by reading books or attending 
PAUD seminars. It is important because the number of working mother keeps on increasing, thus trusting substituting mother role to competent parties in day care who understand children development process is required.

\subsection{Parenting}

Parenting according to (Schochib, 2000:15) is people on duty of guiding, leading or managing. Parenting here means taking care of children to educate and support children, arranging meal, drink, clothing, and their success in the first period until they end up adult. With the aforementioned definition it is understood that child parenting means leadership and guidance to children concerning their life.

Guidance toward children must be conducted constantly to develop children basic competencies. This is in accordance with constructivism theory (Vygotsky, 1978) on early childhood development stating that on children, knowledge is fabricated internally along their experience, observation, and comprehension assisted by adults. The expected result from implementing constructivism is the establishment of an expected attitude getting positive encouragement and less appropriate attitude getting negative encouragement. The theory dictated for parents to limit giving verbal instruction with long sentences, but user short instructions instead followed by constantly demonstrating examples.

There are 2 related factors for children development: (1) mother-children two-way interraction, and (2) continuous stimulation. Therefore parenting is a form of interaction and stimulation delivery from surrounding adults in a child's life. Parents as children primary caregiver at home possess a parenting model where parents expect their children to have autonomy, appropriate, confidence, curiosity, friendly manner, and success oriented.

Parents have a multitude of roles and functions in a family, one of which is responsible for parenting children. Gunarsa (2002:16) stated that parenting is parent's attitude in interacting with the children. The attitude includes way of parents enforcing rules and considerations. Parenting as a parent treatment in fulfilling needs, giving protection, and educating children in daily parent-children interaction.

Experts state that parenting is an importan and fundamental part, preparing children for a civic society. Parenting is closely related to family values.
It is parent's responsibility to equip children and supervising them, assisting them to live life successfully.

Hidayat stated (in Mashar, 2011:17), parenting was created by ever evolving daily interaction between parents and children, thus parents will have children who resemble them, since parents educate not only with words and example, but also with easy to understand advices.

Parenting enable children to be responsible, to be good in society, possessing good characters. What parents do when the child is sick, when the child won't eat, when sad, when a child crying, when a child being aggressive, or when a child lies. According to Sunarti (2004:51), parents are required to be more ready in acting parenting role toward children for them to possess life skills and building optimal autonomy when they mature.

\subsection{Autonomy in Early Childhood}

Parker (in Yamin and Sanan, 2010: 88) says that independence is the ability to manage personal property, know how to manage time, walk and think independently, accompanied by the ability to take risks and solve problems.

Meanwhile, Koencaraningrat (in Yamin and Sanan, 2010: 88) defines independence as part of personality which is a composition of elements of reason that can determine differences in behavior or actions of each individual. Independence in children manifests when using his own mind in making various decisions from choosing the learning equipment he wants to use, choosing playmates, to things that are relatively more complicated and include certain consequences that are more serious.

According to Yamin and Sanan (2010: 83-84), there are characteristics that can show the independence of early childhood children, namely:

a. Children can do all their own activities even though they remain with the supervision of parents/ adults around them.

b. Children can make decisions and choices according to their views, the views themselves can be obtained by children from seeing the behavior or actions of people around them.

c. Children can socialize with other people without being accompanied by parents/ caregivers.

d. Children can control their emotions even empathize with others. 
Shaping the independence of young children depends on the parents in paying attention to the child's psychological growth and development. Of course this is the duty of parents to always accompany their children, because parents are the closest and have direct contact with them. The role of parents or environment towards the growth of independence in children from an early age is an important matter. This is due to the fact that independence in children cannot occur by itself. Children need support, such as positive attitudes from parents and skills training to achieve independence.

In instilling independence in children, it is not permissible to do it with orders and ultimatums because it can make children always feel that they are below their parents and do not have personal authority. Discipline and respect can still be trained without parents becoming fierce to children. Directing and talking with children will be more effective than governing, especially if the command is not based on clear reasons.

This is in accordance with the Theory of Constructivism according to Vygotsky (1978) which states that individuals are reactive beings who respond to the environment by emphasizing the experience and maintenance that will shape their behavior.

Based on this theory, it can be understood that independence can be developed with good environmental influences that provide experience through observation to form habituation, trial and error. Always say and show love, affection and support for toddlers consistently, this will increase their confidence. Thus the child will be more confident in his or her own self, and not hesitate to try new things.

Parents must also be positive towards children as a form of support for the independent efforts of children. There is an appreciation for the child's efforts to become an independent person, regardless of whether at that time he succeeded or not.

With the growth of valuable feelings, the child will have the confidence that is needed in the process of further development. No matter how dirty the child is when he tries to eat himself, no matter how fragile the child is when he tries to bathe himself, however long it takes the child to wear socks and choose the right shoes or clothes, parents should be patient to not react negatively to the child, such as by denouncing or belittling a him/her.
In addition, to be an independent person, a child also needs to have the opportunity to practice consistently doing things themselves or getting used to doing their own tasks in accordance with their age. Parents or the environment do not need to be too anxious, too protective, too helpful or even take over the tasks that children should do, because this can hamper the process of achieving children's independence.

Independence is not a skill that appears suddenly but needs to be taught and trained continuously on an ongoing basis so that it becomes a habit for children from an early age, because if children do not learn independently from an early age it will be very possible for them to feel confused even they may not know how to help themselves in adulthood.

From the description, it can be concluded that independence is a condition where someone can stand alone without relying on others, can do their own activities, can make their own decisions in action, and can empathize with others, and many aspects of independence that can be developed for children ranging from dealing with situations in the environment to interaction with others, so that children are able to think and act on their own. With the ability of independence, children can choose a way of life to develop into a better independent person.

\subsection{Social and Emotional Abilities in Early Childhood}

Ability is the capacity of an individual to perform various tasks in a job which is an innate ability since the child was born or is the result of training or practice. In developing social emotional abilities in early childhood, proper understanding is needed so that children's social emotional abilities develop well according to their development.

This is in accordance with the Constructivism Theory (Vygotsky, 1978) which says that learning is a process to build knowledge through real experience from the field. In the theory of constructivism, evaluation is not only intended to determine the quality of students in understanding the material from the teacher. Evaluation is a suggestion to find out the shortcomings and advantages of the learning process.

Based on this theory, it can be concluded that children's emotional social abilities are built through 
their mentality to master the things learned through their experiences, observations and understanding.

Emotional development in early childhood can get disturbances both internally and externally. The factors that can influence emotional social development in children are:

a. Influence of individual circumstances themselves

b. Conflicts in the development process

c. Environmental causes

\subsection{Day Care}

Day Care is one form of Early Childhood Education (ECE) on the path of non-formal education as a means of welfare that serves as a substitute for the family for a certain period of time for children whose parents work. Day care is an ECE service that organizes education as well as care for children from birth to the age of six.

The need for day care begins with the emergence of parental awareness of the importance of early care and education in families. Due to the condition of working parents and the absence of competent parties in developing children's abilities, an institution is established to replace the function of care and education for children when parents work. The need for day care is also increasingly important because the existence of these institutions can help parents shape their personality, instill religious values, norms, attitude, character, intelligence, tolerance, ethics and aesthetics in children. In this case, day care is the best solution for working parents who expect safety for their children and get a good education.

According to Wahyuti (in PADU Bulletin, 2005: 24), in addition to providing child welfare services, day care also aims to develop various potential children from an early age as preparation for life and can adapt to their environment.

According to the Ministry of National Education (2007) there are 3 types of day care when viewed from its form and character, namely:

1. Full-day day care, where the child is in the institution for a full day, usually for 9 hours.

2. Half-a-day day care, where children are left in the institution for half a day or for 5 hours.

3. Incidental day care, that is a day care that serves child care for just a few hours, usually carried out at any time if necessary according to parental needs.
In addition, the quality of care that is available in every day care also varies. Some caregivers do not receive previous training, while others receive intensive training. Besides, there are day care which has a low child-care ratio and there are also day care which has a high child-care ratio. Comparison of the number of caregivers is calculated as a whole because it takes care of children of all ages.

\section{METHOD}

This study used qualitative descriptive research approach. According to Moleong (2000: 4) qualitative research is research that intends to understand the phenomenon of what is experienced by the research subject holistically and by way of description in the form of words and language in a particular context experienced and by utilizing various scientific methods. The determination of research subjects in qualitative research was carried out purposively, namely Day Care with a 2-3 years age range.

The data collection techniques used was interviews, observation and documentation. According to Patton (in Moleong, 2000: 103) qualitative data analysis is the process of arranging data sequences, organizing them into a pattern, category and unit of basic description by giving significant meaning to the analysis, explaining the pattern of descriptions, and looking for relationships between description of dimensions.

The data analysis was carried out in a process. In this study, data analysis research used was interactive model proposed by Miles and Huberman (in Sugiyono, 2011: 330) which states that qualitative data analysis is carried out interactively and continues to completion, until the data obtained is saturated. So that when conducting an interview, the researcher conducted an analysis of the answers interviewed. If the answer from the interview is analyzed and feels less satisfactory, then the researcher will continue the question again until the required data is obtained. Likewise on data collection techniques with observation and documentation.

Miles and Huberman (in Sugiyono, 2011: 335) explain that there are three steps in data analysis, namely data reduction, data display, and conclusion drawing/ verification.

The data validity test in qualitative research according to Moleong (2000: 173) includes 
credibility tests (internal validity), transferability (external validity), dependability (reliability), and confirmability (objectivity). But the main thing is testing the credibility of the data. The credibility test is carried out by extension of observation, increasing persistence, triangulation, discussion with peers, member checks, and negative case analysis.

In this study, the credibility test was carried out using triangulation. There are several types of triangulation including source triangulation, method, investigator and theory. This study used a type of triangulation method, meaning researchers use different data collection techniques to get data from the same source. For example the data was obtained by interview, then checked by observation and continued by merging the data in documentation. If the three techniques of testing the credibility of the data, produce different data, the researcher conducts further discussions with the relevant sources or others, to ascertain which data is considered correct. Or maybe everything is right, because the point of view is different.

\section{RESULT AND DISCUSSION}

This study aims to observe the behavior of early childhood in the age of 2 - 3 years who are in day care. The behavior observed is the development of children's independence and social-emotional abilities before and after being given care in day care. In qualitative research, there is a need to clarify the condition of a research site to get to know the situation in the place that will be used as a target for the research location, and to get to know more about the children in the place of care.

The number of respondents who were the subjects in this study amounted to 5 children out of all 12 children in day care. The age range that is suitable for the purpose of this study is at the age of 2-3 years with good physical and mental conditions and comes from families with both working parents and sufficient economic standards. Children who are the subject of research have various abilities according to age and character that has been formed from the care of their parents.

Based on the administration data on day care and the children's diaries, preliminary data on children's behavior was obtained (initial entry of children up to one month) which was then used as a reference in observing changes in children's behavior before and after attending a day care program. This preliminary data was explained in the form of a record of the children's initial behavior as a respondent, especially related to independence and social emotional skills.

This research is arranged in narrative form as stated by Miles and Huberman (in Sugiyono, 2011: 339) whose method is frequently used to present qualitative research data in the form of narrative text.

In this qualitative research, credibility tests (internal validity), transferability (external validity), dependability (reliability) and confirmability (objectivity) are needed. Especially in the case of data credibility testing, it is very necessary in qualitative research to make more observations and increase persistence in data collection.

Presentation of data in this study also uses a triangulation approach and discussion with various peers. In this triangulation, the type of parenting triangulation used is that researchers use different data collection techniques to get the same results. The data presented in this study is also derived from the interviews with caregivers, observation data on children's independence and social-emotional observation on the children.

The method which is used to develop independence in children in day care is by using care through continuous interaction with children to find out the response shown by them. This interaction is done directly to each child and repeatedly to develop children's understanding abilities. This is related to the theory of constructivism (Vygotsky, 1978) which states that knowledge in children is created from within them through their own experiences, observations and understanding that can be realized through the help of adults.

Caregiving methods conducted by caregivers are obtained from children's records and from observations through interviews and observations. Treatment and stimulation of each child is different, because it is adjusted to the child's basic understanding ability. So that parenting treatment may not be the same. The caring process carried out by caregivers to children has significantly enabled children to become responsible individuals and have good characters. The caregiver treatment when the child is sick, when the child does not want to eat, when the child is sad, when crying, when acting aggressively, or when the child is lying, requires readiness and proper treatment so that the child has life skills and can build optimal self-reliance and emotional social abilities later as an adult. 
Therefore, every form of care provided by caregivers to children will be understood as a form of stimulation that will provide specific changes in children's attitudes and behavior, especially in the formation of emotional and social independence. Children will respond to any stimulation provided by caregivers as a form of experience that will determine the development of children's understanding in the future. Therefore caregivers are required to provide positive stimulation, because children with a positive environment will perform appropriate changes in attitude. It is intended that the child has mental readiness and skills to prepare the child in the future, while the negative environment will actually have a long-term adverse effect on children. Therefore caregivers must consider every care and action that will be given to the child according to the child's condition.

\section{CONCLUSION}

Based on the results of the research conducted in day care about parenting in developing independence and emotional social abilities in children aged 2-3 years, it can be concluded that parenting is carried out by providing continuous assistance through habituation by starting assistance and giving examples of activities that will be carried out by children, because it has a very important role in understanding the value of independence and social-emotional skills. This is evident in children aged 2-3 years in day care who are able to show improvement in development in terms of independence and social-emotional abilities with a time of between 2-3 months after the child has been in the day care.

Different children's basic abilities will be adjusted to the age level of the child in receiving care provided so that there are children who are able to perform independently with only a little help from their caregivers. Care is used in developing independence and social-emotional abilities through individual and intensive mentoring, consistent habituation and the provision of appropriate examples. The caregivers continually provide training to encourage habituation to children with little help when needed.

\section{REFERENCES}

[1] Amien, Ella Sulhah S. 2005. Pengalaman Mengelola Taman Penitipan Anak. Buletin PADU Jurnal Ilmiah Anak Usia Dini "Penitipan
Anak Sebuah Kebutuhan", Volume 4 No. 2, Agustus 2005. Jakarta: Dit. PADU Depdiknas.

[2] Anonim. theories.com/vygotskys-socitp://www.learningtheory.html. Diunggah pada tanggal 22 Februari 2014.

[3] Arikunto, Suharsimi. 2010. Prosedur Penelitian. Jakarta: Rineka Cipta.

[4] Asmawati, Luluk. 2008. Pengelolaan Kegiatan Pengembangan AUD. Jakarta: Universitas Terbuka.

[5] Belsky, Jay. 2009. Effects Of Child Care On Child Development : Give Parents Real Choice. Institute for the Study of Children, Families and Social Issues. Birkbeck University of London.

[6] Bruce, Tina \& Maggit, Carolyn. 1999. Child Care \& Education. London: Hodder \& Stoughton.

[7] Direktorat PAUD, Ditjen PLS. 2004. Sekilas Taman Penitipan Anak. Jakarta: Depdiknas.

[8] Depdiknas. 2002. Acuan Penyelenggaraan Taman Penitipan Anak. Jakarta: Depdiknas Direktorat Jenderal Pendidikan Luar Sekolah Direktorat Pendidikan Anak Usia Dini.

[9] Departemen Pendidikan dan Kebudayaan. 2007. Undang-undang No.20 Tahun 2009. Tentang Sistem Pendidikan Nasional. Depdiknas: Jakarta.

[10] Depdiknas. 2007. Pedoman Teknis Penyelenggaraan Taman Penitipan Anak. Jakarta.

[11] Ford, Gina. 2000. From Contented Baby to Confident Child. London: Vermillion.

[12] Gerungan. 2004. Psikologi Sosial. Bandung: Refika Ditama

[13] Goleman, Daniel. 1995. Emotional Intelligence. Jakarta: PT Gramedia Pustaka Utama

[14] Gunarsa, Singgih B, 2002, Dasar dan Teori Perkembangan Anak, PT. BPK Gunung Mulia, Jakarta.

[15] Gonzalez, Janet-Mena, Widmeyer, Diane. 2001. Infant, Toddler and Caregivers. London: Delmars Publishers

[16] Hurlock, Elizabeth B. 1999. Perkembangan Anak. Jilid 2. Jakarta : Erlangga.

[17] Hasan, Maimunah. 2012. Pendidikan Anak Usia Dini.oJogjakarta: Diva Press

[18] Howes, C. and L.M. Sakai. 1992. Family day care for infants and toddlers. In D. L. Peters and A. R. Pence, Family Day Care: Current Research for Informed Public Policy. New York: Teachers College Press.

[19] Hariwijaya, M. dan Sukaca, Bertiani Eka. 2007. PAUD Melejitkan Potensi Anak dengan Pendidikan Sejak Dini. Bandung

[20] Hohmann, Mary and Weikart, David P. 1995. Educating Young Children, Active Learning Practices for Preschool and Child Care Programs. Michigan: Ypsilanti.

[21] Indira, Theresia S. 2008. Pola Asuh Penuh Cinta. http://www.polaasuhpenuhcinta.com. Diunggah pada tanggal 30 Januari 2014. 
[22] Johnson, James E. Christie, James F. Wardle, Francis. 2005. Play, Development and Early Education.

[23] Moleong, Lexy J. 2000. Metodologi Penelitian Kualitatif. Bandung.

[24] Morrissey, T. W. 2010. Sequence of child care type and child development: What role does peer exposure play? Early Childhood Research Quarterly, 25, 33-50

[25] Mashar, Riana. 2011. Emosi Anak Usia dini dan strategi pengembangannya. Jakarta: Kencana Prenada Media Group.

[26] Martinis, Yamin dan Sanan, Jamilah Sabri. 2010. Panduan Pendidikan Anak Usia Dini. Jakarta: Gaung Persada (GP) Press Jakarta.

[27] Newjoesafira. 2012. Beberapa-Faktor-YangMempengaruhi Perkembangan Sosial Dan Emosional Anak Usia Dini. Diakses pada tanggal 26 Desember 2013 di http://newjoesafirablog.blogspot.com

[28] Olds, A. R. 2001. Child Care Design Guide. New York: McGraw-Hill.

[29] Patton. 1980. Pengorganisasian Ke Dalam Suatu Pola. Yogyakarta: Graha Ilmu

[30] Peraturan Menteri Pendidikan Nasional Republik Indonesia. Nomor 58 Tahun 2009. Tentang Standar Pendidikan Anak Usia Dini. Jakarta.

[31] Putra dan Dwilestari. 2012. Penelitian Kualitatif: Pendidikan Anak Usia Dini. Jakarta.
[32] Petranto, Ira. 2005. Pola Asuh Anak. http://www.polaasuhanak.com. Diunggah pada tanggal 30 Januari 2014

[33] Ramli. 2005. Pendampingan Perkembangan Anak Usia Dini. Jakarta:Departeman Pendidikan Nasional

[34] Santrock, John. 2009. Perkembangan Anak. Jakarta: Erlangga

[35] Santrock, John. 2002. Perkembangan Masa Hidup. Jakarta : Erlangga

[36] Sugiyono. 2011. Metode Penelitian Kuantitatif dan Kualitatif dan R\&D. Bandung:Alfabeta

[37] Sunarti, E. 2004. Pembelajaran Keterampilan Hidup yang Menyenangkan (Joyfull Learning of Life Skills). Bogor

[38] Shochib, Moh. 2000. Pola Asuh Orang Tua Dalam Membentuk Anak Mengembangkan Disiplin Diri. Jakarta: PT Rineka Cipta.

[39] Suyadi dan Ulfah, Maulidyah. 2013. Konsep Dasar PAUD. Bandung: PT Remaja Rosdakarya

[40] Taufik, Rina M. 2007. Pola Asuh Orang Tua http://www.tabloid_nakita.com. Diunggah pada tanggal 11 Maret $2 \overline{0} 14$.

[41] Tohirin. 2012. Metode Penelitian Kualitatif dalam Pendidikan dan Bimbingan Konseling. Depok: PT Rajagrafindo Persada.

[42] Undang-Undang Republik Indonesia. Nomer 4 Tahun 1979, Tentang Kesejahteraan Anak

[43] Undang-Undang Republik Indonesia. Nomer. 20 Tahun 2009. Tentang Sistem Pendidikan Nasional. Depdiknas: Jakarta. 